\title{
MULTIPLICIDADE COMO RESISTÊNCIA
}

\author{
Antonio Carlos Dias Junior ${ }^{1}$ \\ Wenceslao Machado de Oliveira Junior ${ }^{2}$
}

A Revista ETD-Educação Temática Digital tem o prazer de apresentar seu primeiro número de 2019. Como compromisso público com a pluralidade do pensamento educacional, apresentamos às leitoras e aos leitores quinze textos inéditos, submetidos em demanda contínua ao longo de 2018: doze artigos, um relato de experiência, uma revisão de literatura e uma resenha.

Neles poderão ser lidos aspectos muito variados das forças e preocupações que atravessam a educação contemporânea, tais como as relações de gênero nos eventos esportivos e culturais; a montagem do pensamento e da escrita em educação; as relações de poder que atuam nos corpos coletivos nos cotidianos escolares; a ontologia da formação póshumanista; as práticas de governamento docente presente em livros de formação de professores; as práticas e políticas em cinema-educação na América Latina; as percepções juvenis acerca do significado da experiência socioeducativa de internação como medida educativa e socializadora; a resiliência em jovens expostos ao bullying escolar; as noções de aventura e diversão e o turismo que infantiliza os viajantes; a percepção de universitários sobre a influência de recursos computacionais e incentivo dos professores para sua aprendizagem; as dissertações e teses nacionais relacionadas a Blended Learning; os conceitos de cartografia e mapas, rizomas e desterritorialização/reterritorialização para pensar as aulas de geografia; a docência e as contribuições das experiências de vida à formação inicial de professores; os mapas conceituais na aprendizagem dos estudantes universitários e os desafios éticos e políticos das fake news no contexto da pós-verdade.

\footnotetext{
${ }^{1}$ Doutor e Pós-Doutor em Sociologia - Universidade Estadual de Campinas (UNICAMP) - Campinas, SP - Brasil. Professor - Universidade Estadual de Campinas, Faculdade de Educação (UNICAMP/FE) - Campinas, SP - Brasil. E-mail: acdiasjr@gmail.com

2 Pós-doutorado - Universidade do Minho/Portugal. Doutorado em Educação - Universidade Estadual de Campinas (UNICAMP/FE) - Campinas, SP - Brasil. Professor - Universidade Estadual de Campinas (UNICAMP/FE) - Campinas, SP - Brasil. E-mail: wenceslao.oliveira@gmail.com
}

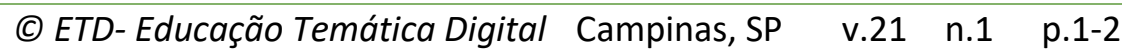
jan./mar. 2019 
Este conjunto variado de temas e abordagens apontam o quanto a educação contemporânea não se restringe às escolas e demais instituições educacionais, mas se espraia por toda a sociedade. A educação tem sido entendida como um conjunto complexo e multifacetado de práticas educativas que se dão misturadas a inúmeras outras práticas sociais que se efetivam tanto em corpos individuais de crianças, jovens, adultos e idosos quanto em corpos coletivos onde estes corpos individuais se relacionam em uma infinita combinação entre eles e os demais corpos não-humanos que configuram todo território habitado pelos humanos.

Este mesmo conjunto variado de questões e propostas, de análises e temas explicita também o quanto a multiplicidade presente em nossa publicação tem sido um gesto de resistência a qualquer tentativa de modelo único de educação, a qualquer tentativa de simplificação da complexidade educacional numa sociedade tão diversa e tão marcada por processos de transformação recente e, sobretudo, a qualquer tentativa de restrição da liberdade dos professores e professoras, de pesquisadores e pesquisadoras para pensarem suas próprias práticas e outras práticas educativas que se coloquem como possíveis no exercício efetivo da educação.

Tendo em vista que há demasiados sinais de que esta liberdade - e esta multiplicidade - está ameaçada, a Comissão Editorial da Revista tomou a decisão de publicar o dossiê "Luto é verbo - educação e democracia", em julho de 2019, o qual será composto pelos textos aprovados na chamada pública que se encontra aberta até meados de fevereiro de 2019 para submissões em português, espanhol e inglês.

A fotografia de capa deste primeiro número foi escolhida neste contexto de incertezas e lutas. Nela vemos, em um plano figurativo, "de fundo", um caminho pouco nítido, apesar de reconhecível como caminho, que sofre interferências no plano da tela, "num fictício primeiro plano superficial", de linhas aleatórias e brilhantes que capturam nosso olhar e tensionam a figura do caminho, criando ainda menos nitidez e certeza ao mesmo tempo que propõem outros caminhos, menos figurativos, para circularmos pela imagem. Caminhos múltiplos que resistem à captura de um só caminho... e forçam a imagem (a vida) a re-existir como multiplicidade. 